\title{
THERMAL GRADIENTS OF CONTAINER AND MEAN SURFACE TEMPERATURE OF BROILER CHICKS TRANSPOR TED ON DIFFERENT SHIPMENTS
}

Doi:http://dx.doi.org/10.1590/1809-4430-Eng.Agric.v36n4p 581-592/2016

\section{AÉRICA C. NAZARENO ${ }^{1 *}$, IRAN J. O. DA SILVA ${ }^{1}$, ANA C. DONOFRE ${ }^{1}$}

\begin{abstract}
This study aimed to evaluate the thermal gradients between the container environment and the interior of chick boxes and mean surface temperature of broiler chicks during transportation on different shipments. The research was conducted in the state of São Paulo, Brazil, with the accompaniment of nine shipments with different density boxes, using an acclimatized truck with an average capacity of 380 boxes. It was selected 14 chick transportation boxes on each shipment and, subsequently, five chicks per box. It was measured the mean surface temperature of chicks (MST) in shipment (loading and unloading) by using an infrared thermometer. In the container microclimate assessment (center and inside chick boxes), it was recorded the air temperature $(\mathrm{T})$, relative humidity $(\mathrm{RH})$ and specific enthalpy (h). For this, 17 data loggers were placed one per box (14) and three along the container. The experimental design was the completely randomized in a $9 \times 2$ factorial scheme. It was found that there are two microclimates in the chick loads, being the highest averages of T, RH and h observed inside boxes. The highest values of MST occurred during the unloading of chicks. It was also observed that the chicks have undergone thermal stress during transportation.
\end{abstract}

KEY WORDS: ambience, pre-farm gate practices, poultry production, acclimatized truck, live load.

\section{INTRODUCTION}

Shortly after hatching, day-old chicks are transported to poultry farms and during this process are subjected to different transport conditions that can harm their welfare, as well as their productive performance. Acclimatized trucks used in poultry production have a great thermal heterogeneity and inadequate ventilation in the container environment (QUINN \& BAKER, 1997; NAZARENO et al., 2015a). The load density of one-day chick varies according to the supply and demand of the hatchery and may exceed 60,000 chicks transported in the same container, increasing the thermal pockets at different load points (NAZARENO et al., 2015a, 2015b).

According to MARQUES (1994), the ideal air temperature and relative humidity for chick transportation varies from 22 to $31{ }^{\circ} \mathrm{C}$ and $50 \%$, respectively, with equivalent air renewal of $30 \mathrm{~m}^{3}$ 1,000 chicks $^{-1}$ hour $^{-1}$. NAZARENO et al. (2015a, 2015b) identified several thermal pockets along the truck container that transport chicks using the variable records air temperature and relative humidity inside boxes. However, these authors did not evaluate the thermal gradient between the two load environments. In addition, it is not known the consequences of this gradient on the chick physiological responses, such as the mean surface temperature.

YAHAV et al. (2009) and NASCIMENTO et al. (2014) observed the microclimate influence of raising poultry farms (air circulation, relative humidity and air te mperature) on the maintenance of body temperature in broiler chickens. According to MARCHINI et al. (2007), ABREU et al. (2012) and NASCIMENTO et al. (2013), the ideal mean surface temperature of day-old chicks ranges from 31.6 to $36.9{ }^{\circ} \mathrm{C}$. The surface temperature of chicks is similar to the ambient temperature, which explains the reduced ability for chicks in losing thermal energy in a sensible form at elevated temperatures (LIN et al., 2005; NÄ̈̈S et al., 2014). However, some stud ies have shown that the existing thermal gradient between the body surface temperature and the air temperature in cold condition are considerably extended due to the day-old chick low

\footnotetext{
${ }^{1}$ NUPEA - Department of Biosystems Engineering - ESALQ/USP/Piracicaba - SP, Brazil.

*Corresponding author. E-mail: aericacn@y ahoo.com.br

Received in: 6-9-2015

Accepted in: 4-20-2016
} 
thermoregulatory capacity and its ease in losing thermal energy to a cooler environment (GUSTIN, 2003).

Aiming at improving the thermal efficiency of trucks that transport chicks, it is important to consider the two microclimates in the container (total and inside boxes) and relate them to some chick physiological variable. In response, it will minimize the container thermal heterogeneity, a better thermal comfort for the chick and the reduction of pre-farm gate losses (chick culling, diseased animals, loss of body mass in the first three weeks of life and mortality).

Given this issue, the aim of this study was to evaluate the thermal gradients between the container environment and the interior of chick boxes and the mean surface temperature of broiler chicks during transportation on different shipments.

\section{MATERIAL AND METHODS}

The research was conducted in a poultry hatchery of an integrated company located in São Paulo State, Brazil, with latitude of $22^{\circ} 25^{\prime} 55^{\prime}$ ' S, longitude of $46^{\circ} 57^{\prime} 28^{\prime}$ ' W, altitude of $632 \mathrm{~m}$ and atmospheric pressure of $761.98 \mathrm{mmHg}$. The experimental period was three months, with the accompaniment of nine shipments of day-old chicks during the spring and summer seasons.

In all shipments was used the same container truck, model Volkswagen Constellation 26-370, $6 \times 4$ tractor, $8 \mathrm{~m}$ long, $2.5 \mathrm{~m}$ wide and $2.5 \mathrm{~m}$ high, with two axes. The truck body was coated internally and externally with aluminum, with thermal insulation of expanded polyurethane. The doors were made of three layers of stainless steel, fully sealed. Inside, there were three rows (central, left and right sides) with spacing of $0.7 \mathrm{~m}$. The sides were longitudinally divided with 2 shelves, with approximate vertical spacing of $0.81 \mathrm{~m}$ from each other.

Sensors controlled the truck internal temperature, ventilation, and humidity. A centrifugal humidifier or pressurized air nozzles, controlled digitally by an electronic system located in the truck cabin, carried out internal humidification. Thermal control was programmed for a temperature between 23 and $25{ }^{\circ} \mathrm{C}$ and relative humidity between 60 and $70 \%$. The truck's acclimatized system was located in front of its body shell, with part of the air circulation distributed through floor vents and air vents (ventilation) located in the openings of the body shell roof (truck ridge vent). It is noteworthy that the acclimatized system was only activated when the truck was in moving.

The boxes used for the chick transportation had $42 \mathrm{~cm}$ wide, $57 \mathrm{~cm}$ long, $15 \mathrm{~cm}$ high and thickness of $2.5 \mathrm{~mm}$. These boxes were provided with 26 ventilators of $1 \mathrm{~cm}$ wide and $6.5 \mathrm{~cm}$ high around. Under normal conditions of transport, these boxes were stacked considering their density and the company's transportation logistics; the last one received a perforated lid to facilitate a minimum air circulation towards the animals during shipment.

Truck carrying capacity was of approximately 380 boxes, with 100 chicks each, and distributed among container rows (Figure 1). However, the study shipments presented different densities of chick boxes $(1=450,2=470,3=450,4=420,5=420,6=360,7=240,8=308,9=$ 300). It is worth emphasizing that each load presented a differentiated distribution of data loggers, as the distribution of lots established by the company (transport logistics), and it could not be changed. 

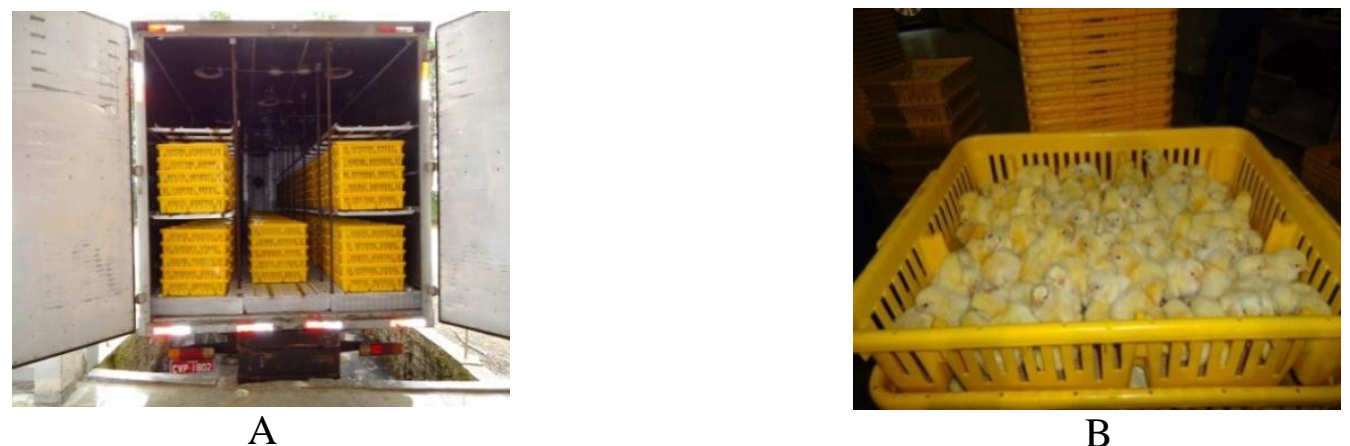

FIGURE 1. Acclimatized transport truck loaded (A) and day-old chicks box (B).

On each shipment, 14 chick boxes of the Cobb Fast strain were selected and five chicks were randomly collected from each of them during shipment (loading and unloading) in order to measure the body surface temperatures (head, back, wing and paw). A Fluke brand infrared thermometer was used, obtaining the mean surface temperature (MST) for the first week of raising, according to [eq. (1)] proposed by NASCIMENTO et al. (2013):

$$
M S T=0.10 * t h+0.56 * t b+0.11 * t w+0.15 * t p+3.7
$$

where,

th is the head surface temperature $\left({ }^{\circ} \mathrm{C}\right)$;

$t b$ is the back surface temperature $\left({ }^{\circ} \mathrm{C}\right)$;

$t w$ is the wing surface temperature $\left({ }^{\circ} \mathrm{C}\right)$, and

$t p$ is the paw surface temperature $\left({ }^{\circ} \mathrm{C}\right)$.

To characterize the thermal environment, the thermal variables air temperature $\left(\mathrm{T},{ }^{\circ} \mathrm{C}\right)$ and relative humidity (RH, \%) were recorded by using 17 data loggers Onset, model Hobo ${ }^{\circledR}$. It was added a data logger inside each of the 14 chick boxes selected on each shipment, which were randomly distributed throughout the container. Furthermore, three data loggers were positioned at the center of the container (central measurements). The equipment was programmed for recording the data at 10-minute intervals.

The average local values of temperature, relative humidity and atmospheric pressure $(761.98$ $\mathrm{mm} \mathrm{Hg}$ ) were used to calculate the specific enthalpy (h, $1 \mathrm{~kJ} \mathrm{~kg}^{-1}$ dry air) by using the equation proposed by RODRIGUES et al. (2011).

The experimental design for evaluating the microclimate of the container consisted of a structure of completely randomized plots and as treatment structure was adopted the factorial scheme $9 \times 2$ (shipments and central and internal box measurements), in which the repetitions were the records of time intervals of each shipment.

For the variable MST, the experimental design was the completely randomized in a $9 \times 2$ factorial scheme (shipments, loading and unloading), with five repetitions (chicks). In the statistical analysis of the container, microclimate was used generalized linear models (MOLENBERGHS \& VERBEKE, 2005). In order to compare the means, it was used the $F$ test at 0.05 probability level. It was also carried out a Pearson correlation at 0.05 probability level for microclimate variables and mean surface temperature of chicks during transportation.

All the statistical analyses were performed using the statistical software SAS (SAS, 2010).

\section{RESULTS AND DISCUSSION}

By means of the slicing interaction of shipments and container measurements (central and inside boxes) for the variable air temperature, it was possible to detect that there was a statistical 
difference $(\mathrm{P}<0.0001)$ between shipments and the two container environments where the chicks were transported (Table 1).

TABLE 1. Measurements of air temperature $(T)$ in different container environments and shipments, with their respective gradients.

\begin{tabular}{|c|c|c|c|}
\hline \multirow[t]{2}{*}{ Shipments } & \multicolumn{2}{|c|}{$\begin{array}{c}\text { Measurements of } \mathrm{T}\left({ }^{\circ} \mathrm{C}\right) \text { in the container } \\
\text { environment }\end{array}$} & \multirow{2}{*}{$\begin{array}{l}\text { Temperature gradients } \\
\qquad\left({ }^{\circ} \mathrm{C}\right)\end{array}$} \\
\hline & Central & Inside the boxes & \\
\hline 1 & $31.0 \mathrm{Bb}$ & $33.1 \mathrm{Ca}$ & 2.1 \\
\hline 2 & $23.3 \mathrm{~Gb}$ & $29.1 \mathrm{Ga}$ & 5.8 \\
\hline 3 & $26.0 \mathrm{Fb}$ & $31.1 \mathrm{Ea}$ & 5.1 \\
\hline 4 & $32.2 \mathrm{Ab}$ & $36.0 \mathrm{Aa}$ & 3.8 \\
\hline 5 & $32.1 \mathrm{Ab}$ & $34.4 \mathrm{Ba}$ & 2.3 \\
\hline 6 & $26.0 \mathrm{Fb}$ & $30.0 \mathrm{Fa}$ & 4.0 \\
\hline 7 & $30.0 \mathrm{Cb}$ & $33.1 \mathrm{Ca}$ & 3.1 \\
\hline 8 & $29.1 \mathrm{Db}$ & $32.2 \mathrm{Da}$ & 3.1 \\
\hline 9 & $28.3 \mathrm{~Eb}$ & $32.4 \mathrm{Da}$ & 4.1 \\
\hline F test & \multicolumn{2}{|r|}{$419.88^{*}$} & \\
\hline Coefficient of variation (\%) & \multicolumn{2}{|r|}{7.84} & \\
\hline $\begin{array}{l}\text { Pearson's correlation } \\
\text { coefficient }\end{array}$ & \multicolumn{2}{|r|}{0.95} & \\
\hline
\end{tabular}

In shipments 4 and 5, the air temperatures at the center of the container were not statistically different from each other, but differed from all others. There was statistical difference between shipments 1, 7, 8 and 9, which differed from the others. However, there was no difference between shipments 3 and 6, but differed from the others. Regarding the air temperature inside boxes, it was observed significant differences between shipments 4 and 5, as well as from other shipments. On the other hand, shipments 1 and 6 did not differ from each other, but differed from the others. There was no statistical difference between shipments 9 and 8 , which differed from the others; shipments 3, 6 and 2 differed from all others and to each other. Moreover, it was observed a statistical difference between air temperature (central and inside boxes) for all studied shipments.

The coefficient of variation of the air temperature measurements was low (7.84\%), demonstrating the homogeneity and the low dispersion $(\mathrm{CV} \leq 15 \%)$ of the data (SAMPAIO, 2007). Regarding the Pearson correlation shown in Table 1, it was observed that there was significant difference $(\mathrm{P}<0.0003)$ between the measurements at the center of the container and inside transported chick boxes, presenting a strong and positive $(0.95)$ correlation coefficient $(\mathrm{P}>0.70)$. Therefore, the air temperature gradient in the truck container was dependent on both environments (central and inside boxes), i.e., the higher the temperature at the center of the truck container is, the higher the temperature inside chick boxes during transportation.

In general, it was found that there is a temperature gradient $\left(2.1\right.$ to $\left.5.8{ }^{\circ} \mathrm{C}\right)$ between the two environments of the container load, where the highest averages of air temperature occurred in the environment inside chick transportation boxes compared to the central part. However, in order to improve the acclimatization system efficiency of the trucks that transport chicks, it is necessary to consider the two microclimates inside container; this is the way to get the ideal conditions of air temperature for chick transportation.

The highest average air temperature $\left(36^{\circ} \mathrm{C}\right)$ was observed in the environment inside chick boxes during shipment 4 , which is above the ideal range. However, in all other shipments, the average values of temperature were within the ideal range $\left(32\right.$ to $\left.35^{\circ} \mathrm{C}\right)$, as recommended by LIN et al. (2005), MUJAHID \& FURUSE (2009) and NASCIMENTO et al. (2012, 2013). 
The air temperature when above the ideal range may induce the chicks to hyperthermia with dehydration, leading to reduction in feed intake and growth retardation. However, temperatures well below the ideal range can trigger hypothermia and induce pulmonary hypertension syndrome (ascites) in broilers (MICKELBERRY et al., 1966; CASSUCE et al., 2013).

When it comes to chick thermal comfort, it is important to remember that other microclimate variables, such as relative humidity, air circulation, among others, may influence thermoneutral zone (YAHAV et al., 2005). Therefore, these variables analyzed together will show whether chicks were under thermal stress or not during transportation.

There was statistical difference $(\mathrm{P}<0.0001)$ in the interaction between shipments and the container measurements (central and inside boxes) for the variable relative humidity in the truck that transports chicks (Table 2).

TABLE 2. Measurements of relative humidity $(\mathrm{RH})$ in different container environments and shipments, with their respective gradients.

\begin{tabular}{|c|c|c|c|}
\hline \multirow[t]{2}{*}{ Shipments } & \multicolumn{2}{|c|}{$\begin{array}{c}\text { Measurements of } \mathrm{RH}(\%) \text { in the container } \\
\text { environment }\end{array}$} & \multirow{2}{*}{$\begin{array}{l}\text { RH gradient } \\
\quad(\%)\end{array}$} \\
\hline & Central & Inside the boxes & \\
\hline 1 & $38.0 \mathrm{Cb}$ & $48.0 \mathrm{Ca}$ & 10.0 \\
\hline 2 & $54.0 \mathrm{Aa}$ & $53.0 \mathrm{Ba}$ & 1.0 \\
\hline 3 & $54.0 \mathrm{Aa}$ & $52.0 \mathrm{Ba}$ & 2.0 \\
\hline 4 & $31.0 \mathrm{Db}$ & $38.0 \mathrm{Fa}$ & 7.0 \\
\hline 5 & $32.0 \mathrm{Db}$ & $41.0 \mathrm{Ea}$ & 9.0 \\
\hline 6 & $48.0 \mathrm{Bb}$ & $57.0 \mathrm{Aa}$ & 9.0 \\
\hline 7 & $33.0 \mathrm{Db}$ & $44.0 \mathrm{Da}$ & 11.0 \\
\hline 8 & $37.0 \mathrm{Cb}$ & $49.0 \mathrm{Ca}$ & 12.0 \\
\hline 9 & $37.0 \mathrm{Cb}$ & $47.0 \mathrm{Ca}$ & 10.0 \\
\hline F test & \multicolumn{2}{|c|}{$71.47 *$} & \\
\hline Coefficient of variation (\%) & \multicolumn{2}{|c|}{26.00} & \\
\hline $\begin{array}{l}\text { Pearson's correlation } \\
\text { coefficient }\end{array}$ & \multicolumn{2}{|c|}{0.85} & \\
\hline
\end{tabular}

Means followed by different letters (uppercase letters on columns and lowercase letters on lines) differ at 0.05 probability level by the F test. NS - not significant; * - Significant at $0.05(\mathrm{P}<0.05)$.

In shipments 2 and 3, the relative humidity measurements at the center of the container were not statistically different from each other, but differed from all others. There was statistical difference in shipment 6 , which differed from the others. However, there was no difference between shipments 1,8 and 9, which differed from the others. Additionally, shipments 7, 5 and 4 did not differ from each other, but were statistically different from the other shipments. Regarding the relative humidity inside boxes, it was observed that shipment 6 was statistically different from the other shipments. Differently, shipments 2 and 3 did not differ from each other, differing only from the others. Besides of that, there was no statistical difference between shipments 8 and 9, which differed from the others. Moreover, shipments 7, 5 and 4 differed from all other shipments and from each other. Also, there was a statistical difference between the measurements (central and inside boxes) for shipments 1, 4, 5, 6, 7, 8 and 9 of the variable relative humidity; however, shipments 2 and 3 did not differ between the measurements during the chick transportation.

The coefficient of variation of the relative humidity measurements was medium (26\%), demonstrating the homogeneity and the average dispersion $(15 \%<\mathrm{CV}<30 \%)$ of the data (SAMPAIO, 2007). Regarding the Pearson correlation shown in Table 2, it was observed that there was significant difference $(\mathrm{P}<0.0037)$ between the measurements at the center of the container and inside transported chick boxes, showing a strong and positive (0.85) correlation coefficient $(\mathrm{P}>0.70)$. Therefore, the relative humidity gradient in the truck container was dependent on both environments (central and inside boxes), i.e., the higher the relative humidity at the center of the 
truck container is, the higher the relative humidity inside chick boxes during transportation.

It was found a relative humidity gradient ( 1 to $12 \%$ ) between the two environments of the container load, where their highest averages occurred in the environment inside chick transportation boxes compared to the central part because the chicks were agglomerated in a smaller space (boxes) in relation to the container. Therefore, the boxes presented a higher concentration of water vapor because of the chick respiration. MARQUES (1994) and QUINN et al. (1997) attributed this heterogeneity to low air circulation inside container and to humidifiers inefficiency, which is attributed to problems in the acclimatization system of trucks, as well as to the non-standardization of density loads in shipments. NAZARENO et al. (2015a, 2015b) found several cores of relative humidity inside transport boxes in the truck, which may have been caused by air circulation, density of uneven loads and pre-gate farm management before loading (wetting the container before starting loading, regardless of how the microclimate of this environment is).

The highest average of relative humidity occurred in shipment 6 and the internal environment of the chick boxes (57\%), which was within the ideal range. However, it was observed that in most of shipments and environment measurements (central and inside boxes) the relative humidity was below the range (50-60\%) recommended by LIN et al. (2005), MUJAHID \& FURUSE (2009) and NASCIMENTO et al. (2012, 2013).

The relative humidity acts on the heat exchange (sensible and latent) of broiler chicks (LIN et al., 2005; SCHMIDT et al., 2009). The loss of evaporative heat (latent) increases with temperature, but decreases with increasing relative humidity; its effect on the chick thermoregulation will depend on the air temperature and chick age (LIN et al., 2005). When the relative humidity is above 60\%, the heat transmission from inside body to the periphery is reduced, which harms the heat exchange with the environment. However, when the relative humidity is below the range of $50 \%$, the heat exchange between animal and environment by latent via are high, which may result in ascites, a pulmonary hypertension syndrome whose consequence is the mucous membrane dehydration of the chicks in the first weeks of life (MUJAHID \& FURUSE, 2009).

Based on the interaction between shipments and container measurements (central and inside boxes) for the variable specific enthalpy in the truck that transports chicks, it was observed a statistically significant difference $(\mathrm{P}<0.0001)$ between the factors evaluated (Table 3$)$.

TABLE 3. Measurements of specific enthalpy (h) in different container environments and shipments, with their respective gradients.

\begin{tabular}{cccc}
\hline \multirow{2}{*}{ Shipments } & \multicolumn{2}{c}{$\mathrm{h}$ in the container environment $\left(\mathrm{kJ} \mathrm{kg}^{-1}\right.$ dry air) } & \multirow{2}{*}{ h gradient } \\
\cline { 2 - 4 } & Central & Inside the boxes & 13.8 \\
2 & $57.4 \mathrm{Ab}$ & $63.0 \mathrm{Aa}$ & 16.0 \\
3 & $47.0 \mathrm{Db}$ & $68.0 \mathrm{Ba}$ & 13.8 \\
4 & $54.2 \mathrm{Bb}$ & $71.1 \mathrm{Aa}$ & 15.1 \\
5 & $56.0 \mathrm{ABb}$ & $69.5 \mathrm{Ba}$ & 13.5 \\
6 & $56.0 \mathrm{ABb}$ & $66.4 \mathrm{Da}$ & 15.3 \\
7 & $51.1 \mathrm{Cb}$ & $67.5 \mathrm{CDa}$ & 15.5 \\
8 & $52.0 \mathrm{Cb}$ & $69.0 \mathrm{Ba}$ & 16.8 \\
9 & $52.2 \mathrm{Cb}$ & $68.0 \mathrm{BCa}$ & 17.0 \\
\hline F test & $51.0 \mathrm{Cb}$ & \multicolumn{3}{c}{$154.18^{*}$} \\
\hline Coefficient of variation $(\%)$ & \multicolumn{4}{c}{0.00} \\
\hline Pearson's correlation coefficient
\end{tabular}

Means followed by different letters (uppercase letters on columns and lowercase letters on lines) differ at 0.05 probability level by the F test. NS - not significant; * - Significant at $0.05(\mathrm{P}<0.05)$.

The specific enthalpy at the center of the container did not differ from each other in shipments 1, 4 and 5; however, they differed from all others, except for shipments 4 and 5 that did not differ 
from shipment 3. There was statistical difference in shipment 3 in relation to the others; however, there was no difference between shipments 7, 8, 9 and 6, which differed from the others. Shipment 2 showed statistical difference compared to the other shipments. Regarding the measurements of specific enthalpy inside boxes, shipments 1 and 4 did not differ statistically from each other, but differed from the other shipments. On the other hand, shipments 5, 3, 8 and 9 did not differ from each other, but differed from the other shipments, except shipment 9, which did not present statistical difference from shipment 7 , which, in turn, differed from the others. Moreover, shipment 7 also did not differ statistically from shipment 6, but differed from all other shipments. There was statistical difference between the measurements of specific enthalpy (central and inside boxes) for all studied shipments.

The coefficient of variation of the specific enthalpy measurements was low (15\%), demonstrating the homogeneity and low dispersion ( $\mathrm{CV} \leq 15 \%)$ of the data (SAMPAIO, 2007). Regarding the Pearson correlation shown in Table 3, it was observed that there was significant difference $(\mathrm{P}<0.0003)$ between the measurements at the center of the container and inside transported day-old chick boxes, showing a strong and positive (0.93) correlation coefficient $(\mathrm{P}>0.70)$. Therefore, the specific enthalpy gradient in the truck container was dependent on both environments (central and inside boxes), i.e., the higher the specific enthalpy at the center of the truck container is, the higher the specific enthalpy inside chick boxes during transportation.

It was found that there is a specific enthalpy gradient $\left(13-17 \mathrm{~kJ} \mathrm{~kg}^{-1}\right.$ dry air) between the two environments of the container load, where their highest averages occurred in the environment inside chick transportation boxes compared to the central part. These results may be explained by the increase in air temperature and relative humidity in the container environment (NAZARENO et al., 2015a, 2015b).

The highest average value of specific enthalpy occurred in shipments 1 and 4 in the internal environment of the chick boxes, with values of 71.2 and $71.1 \mathrm{~kJ} \mathrm{~kg}^{-1}$ dry air, respectively. It was observed that there is a tendency for higher air temperature and lower relative humidity, demonstrating their influence on the specific enthalpy.

In general, the specific enthalpy was out of the recommended range (50 to $60 \mathrm{~kJ} \mathrm{~kg}^{-1}$ dry air) for day-old chicks, considering an average local atmospheric pressure of $761.98 \mathrm{mmHg}$, generated by the air temperature changes and relative humidity. According to ÇENGEL \& BOLES (2001), the higher the specific enthalpy value is, the higher the amount of thermal energy in the dry air. Thus, it could explain what happened in the internal environment of the chick transportation boxes, where the chicks were more agglomerated (100 chicks box ${ }^{-1}$ ) in a smaller space (boxes) compared to the truck container.

The results observed may indicate that broiler chicks suffered heat stress during shipments. Therefore, it is necessary to improve the acclimatization standards of the trucks that transport dayold chicks in order to minimize losses and improve their wellbeing during transportation. The implication of an inappropriate chick transportation (load microclimate outside the ideal range) will only be noticed on the raising farm, when the chicks do not achieve their great growth performance over the 42 days, being part of them discarded and others get died in the first weeks of life (TZSCHENTKE, 2007).

Based on the slicing interaction between travel and shipment (loading and unloading), it was possible to detect that there was a statistical difference $(\mathrm{P}<0.0001)$ for the mean surface temperature (MST) during chick transportation (Table 4). 
TABLE 4. Mean surface temperature (MST) of day-old chicks in different shipments in the loading and unloading of the container truck.

\begin{tabular}{cccc}
\hline \multirow{2}{*}{ Shipments } & \multicolumn{2}{c}{ MST of chick shipments } & \multirow{2}{*}{ MST gradient } \\
\cline { 2 - 3 } & Loading & Unloading & 5.3 \\
2 & $32.9 \mathrm{~Gb}$ & $38.2 \mathrm{Ba}$ & -1.7 \\
3 & $34.9 \mathrm{Fa}$ & $33.2 \mathrm{~Eb}$ & 1.9 \\
4 & $35.2 \mathrm{~Eb}$ & $37.1 \mathrm{Ca}$ & 2.6 \\
5 & $36.1 \mathrm{Ab}$ & $38.7 \mathrm{Aa}$ & 3.0 \\
6 & $35.2 \mathrm{DEb}$ & $38.2 \mathrm{Ba}$ & -0.7 \\
7 & $35.4 \mathrm{CDa}$ & $34.7 \mathrm{Db}$ & 2.2 \\
8 & $35.5 \mathrm{BCb}$ & $37.7 \mathrm{Ca}$ & 3.2 \\
9 & $34.8 \mathrm{Fb}$ & $38.0 \mathrm{Ba}$ & 2.1 \\
\hline F test & $35.7 \mathrm{Bb}$ & $37.8 \mathrm{BCa}$ & \\
\hline \multicolumn{3}{c}{$356.32 *$} \\
\hline
\end{tabular}

Means followed by different letters (uppercase letters on columns and lowercase letters on lines) differ at 0.05 probability level by the F test. NS - not significant; * - Significant at $0.05(\mathrm{P}<0.05)$.

In the loading of shipment 4, the mean surface temperature (MST) of day-old chicks was statistically different from the other shipments. There was no statistical difference between shipments 9 and 7, which differed from the others, except shipment 6, which did not differ from shipment 7. Furthermore, there was no difference between shipment 6 and 5, which differed from the other shipments, except from shipment 4, which did not differ from shipment 5 . Shipment 3 differed from all other shipments. There was no statistical difference between shipments 2 and 8 , differing from the others. Also, shipment 1 differed statistically from all shipments. Regarding the unloading, shipment 4 was statistically different from the other shipments. However, shipments 5, 1,8 and 9 did not differ from each other, but differed from the others, except shipment 9 , which did not differ from shipments 7 and 3, which, in turn, differed from the others. Shipments 6 and 2 differed from each other and from all other shipments. In addition, there was a statistical difference between loading and unloading for the studied shipments.

The coefficient of variation of MST of the chick shipment was low (2.10\%), demonstrating the homogeneity and low dispersion ( $\mathrm{CV} \leq 15 \%)$ of the data (SAMPAIO, 2007).

In general, the chick unloading was the moment of the highest mean surface temperature for most shipments. Additionally, it was observed that there is an mean surface temperature gradient from -1.7 to $5.3{ }^{\circ} \mathrm{C}$, which may be due to the effect of the fluctuation (increase and/or decrease) of the air temperature and relative humidity of the container environment. Several studies on transport of farm animals have shown that shipment (loading and unloading) can be considered as one of the most stressful components (due to microclimatic variations, air circulation, etc.), which alter the animal physiology, such as increased rectal and surface temperatures, cortisol levels, and heart and respiratory rate (ONMAZ et al., 2011; TATEO, et al., 2012).

The highest average of MST $\left(38.7{ }^{\circ} \mathrm{C}\right)$ occurred during the unloading of shipment 4 . This value may be justified by the higher air temperature $\left(36^{\circ} \mathrm{C}\right)$ and lower humidity $(38 \%)$ inside chick containers. GILOH et al. (2012) found a high correlation coefficient between the chick surface temperature and environmental variables, confirming that the air temperature, relative humidity and air circulation are the main factors that affect the chick performance.

In general, the unloading presented the highest average of MST for most studied shipments, which were out of the ideal range $\left(31.6\right.$ to $36.9{ }^{\circ} \mathrm{C}$ ) for the day-old chicks, according to MARCHINI et al. (2007), ABREU et al. (2012) and NASCIMENTO et al. (2013). In birds, surface temperature variations are directly related to peripheral blood flow, which may indicate that the animals are actively trying to keep constant the temperature of the body core.

When there is an increase in surface temperature, it has also an increase in blood flow in the 
body surface and heat loss through sensitive exchange. However, the decreased blood flow is related to peripheral vasoconstriction (by cold stress conditions). The surface temperature is a parameter which varies rapidly with the microclimate changes (air temperature and relative humidity) and can be used as an indication of changes in the peripheral blood flow and heat exchange (NASCIMENTO et al., 2013).

Based on these results, it was possible to observe that there are two microclimates inside truck (container environment and inside chick boxes), with average thermal gradients of $4{ }^{\circ} \mathrm{C}, 6 \%$ and 15 $\mathrm{kJ} \mathrm{kg}^{-1}$ dry air, necessary to achieve the ideal comfort conditions inside chick boxes. Therefore, it is necessary to sum these values to the microclimate records of the container, being possible to estimate the chick thermal comfort.

These thermal gradients may have influenced the increase of the mean surface te mperature of chick during transportation, leading them to a thermal heat stress. In order to minimize thermal heterogeneity along the truck profile, improve the chick thermal comfort and reduce pre-farm gate losses, it is very important to consider these gradients in the two microclimates during the phases of construction and dimensioning of the acclimatization system in containers used for chick transportation.

Regarding the Pearson correlation shown in Table 5, it was observed that there was a significant difference between the microclimate variables and the mean surface temperature.

TABLE 5. Correlations between the truck microclimate variables ( $\mathrm{T}, \mathrm{RH}$ and $\mathrm{h}$ ) and the mean surface temperature (MST) of day-old chicks.

\begin{tabular}{ccc}
\hline Variables & Pearson's correlation coefficient & $\mathrm{P}<0.05$ \\
\hline T and MST & 0.841 & 0.004 \\
RH and MST & -0.782 & 0.012 \\
$\mathrm{~h}$ and MST & 0.720 & 0.020 \\
\hline
\end{tabular}

Pearson correlation at 0.05 probability level $(\mathrm{P}<0.05)$.

The air temperature and specific enthalpy showed strong and positive $(0.841$ and 0.720 , respectively) correlation coefficients $(\mathrm{P}>0.70)$. Therefore, the average surface temperature of chicks during transportation is dependent on the air temperature and specific enthalpy; thus, the higher these microclimate variables in the truck container are, the higher the MST. The relative humidity presented a strong and negative $(-0.782)$ correlation coefficient $(\mathrm{P}>0.70)$. Therefore, the mean surface temperature of chicks during transportation was dependent on the relative humidity; thus, the higher this microclimate variable in the truck container is, the lower the MST.

Based on the Pearson correlation, it was possible to observe that the microclimate variables in the chick truck container influenced the average surface temperature of chicks during transportation.

\section{CONCLUSIONS}

There are two microclimates in the chick load (container environment and inside chick boxes), with the highest average of T, RH and h observed inside chick boxes.

The highest mean surface temperatures were observed in the chick unloading, which may have been caused by the effect of the air temperature and relative humidity fluctuation on both environments of the truck container.

Based on the truck container microclimate and on the mean surface temperature of broiler chicks, it was observed that these poultry were under heat stress during transportation.

\section{ACKNOWLEDGEMENTS}

We are grateful to the CNPq for granting the scholarship and to the São Paulo Research Foundation (FAPESP) for the financial support. 


\section{REFERENCES}

ABREU, P. G.; ABREU, V. M. N.; COLDEBELlA, A.; HASSEMER, M. J.; TOMAZELLI, I. L. Medidas morfológicas em função do peso e da idade da ave, por meio de imagens. Revista

Brasileira de Engenharia Agrícola e Ambiental. Campina Grande, v.16, p.795-801, 2012. Disponível em: <http://www.scielo.br/scielo.php?script=sci_arttext\&pid=S141543662012000700014>. doi: 10.1590/S1415-43662012000700014

CASSUCE, D. C.; TINÔCO, I. F.F.; BAÊTA, F. C.; ZOLNIER, S.; CECON, P. R.; VIEIRA, M. F. A. Thermal comfort temperature update for broiler chickens up to 21 days of age. Engenharia Agrícola, Jaboticabal, v.33, p.28-36, 2013. Disponível em:

<http://www.scielo.br/pdf/eagri/v33n1/v33n1a04.pdf>. doi: 10.1590/S0100-69162013000100004

ÇENGEL, Y. A.; BOLES, M. A. Termodinâmica. $3^{\text {rd }}$. ed.Mcgraw-hill, Alfragide: 2001. 900p.

GILOH, M.; SHINDER, D.; YAHAV, S. Skin surface temperature of broiler chickens is correlated to body core temperature and is indicative of their thermoregulatory status. Poultry Science, Sarvy, v.91, p.175-188, 2012. Disponível em: < http://ps.oxfordjournals.org/content/91/1/175.full.pdf > doi: 10.3382 / ps.2011-01497

GUSTIN, P.C. Manejo dos pintos no incubatório, expedição, transporte e alojamento na granja. In: MACARI, M.; GONZALES, E. (Ed.). Mane jo da incubação. Jaboticabal: FACTA, 2003. p. 199266.

LIN, H.; ZHANG, H. F.; JIAO, H. C.; ZHAO, T.; SUI, S. J.; GU, X. H.; ZHANG, Z. Y.; BUYSE, J.; DECUYPERE, E. Thermoregulation responses of broiler chickens to humidity at different ambient temperatures. I. one week of age. Poultry Science, Sarvy, v.84, p.1166-1172, 2005. Disponível em: <http://ps.oxfordjournals.org/content/84/8/1166.long>. doi: 10.1093/ps/84.8.1166.

MARCHINI, C. F. P.; SILVA, P. L.; NASCIMENTO, M. R. B. M.; TAVARES, M. Frequência respiratória e temperatura cloacal em frangos de corte submetidos à temperatura ambiente cíclica elevada. Archives of Veterinary Science, Curitiba, v. 12, n.1, p.41-46, 2007. Disponível em: <http://ojs.c3sl.ufpr.br/ojs2/index.php/veterinary/article/view/9227/6453>. doi: 10.5380/avs.v12i1.9227

MARQUES, D. Fundamentos básicos de incubação industrial. 2. ed. São Paulo: CASP, 1994. $143 p$.

MICKELBERRY, W. C.; ROGLER, J. C.; STADELMAN, W. J. The influence of dietary fat and environmental temperature upon chick growth and carcass composition. Poultry Science, Sarvy, v.45, p.313-321, 1966.

MOLENBERGHS, G.; VERBEKE, G. Models for discrete longitudinal data. New York: Springer, 2005. 671p.

MUJAHID, A.; FURUSE, M. Oxidative damage in different tissues of neonatal chicks exposed to low environmental temperature. Comparative Biochemistry and Physiology Part A, New York, v.152, p.604- 608, 2009. Disponível em: < http://ac.els-cdn.com/S1095643309000294/1-s2.0S1095643309000294-main.pdf?_tid=9072390c-dc68-11e4-a5c700000aab0f6b\&acdnat=1428330418_d865b1b7d024066b35400808c86dc9b1>. doi: 10.1016/j.cbpa.2009.01.011

NÄÄS, I.A.; GRACIANO, D.E.; GARCIA, R.G.; S ANTANA, M.R.; NEVES, D.P. HEAT LOSS IN ONE DAY OLD PULLETS INSIDE A HATCHERY. Engenharia Agrícola, Jaboticabal, v.34, p.610-616, 2014. Disponível em: <http //www.scielo.br/pdf/eagri/v34n4/01.pdf>. doi:

$10.1590 / \mathrm{S} 0100-69162014000400001$ 
NASCIMENTO, G. R.; NÄÄS, I. A.; BARACHO, M. S. PEREIRA, D. F.; NEVES, D. P. Termografia infravermelho na estimativa de conforto térmico de frangos de corte. Revista

Brasileira de Engenharia Agrícola e Ambiental, Campina Grande, v.18, n.6, p.658-663, 2014. Disponível em: < http://www.scielo.br/scielo.php?pid=S1415-

43662014000600014\&script=sci_arttext $>$. doi: 10.1590/S1415-43662014000600014

NASCIMENTO, S. T.; SILVA, I. J. O.; MAIA, A. S. C.; CASTRO, A. C.; VIEIRA, F. M. C. Mean surface temperature prediction models for broiler chickens-a study of sensible heat flow.

Inte rnational Journal of B iometeorology, Heidelberg, v.1, p.1-7, 2013. Disponível em: $<$ http://www.nupea.esalq. usp.br/imgs/producao/Journal-International-biometeorology-10-1007s00484-013-0702-7.pdf>. doi: 10,1007 / s00484-013-0702-7

NASCIMENTO, S. T.; SILVA, I. J. O.; MOURÃO, G. B.; CASTRO, A. C. Bands of respiratory rate and cloacal temperature for different broiler chicken strains. Revista Brasileira de Zootecnia, Brasília, v.41, p.318-1324, 2012. Disponível em:

<http://www.scielo.br/scielo.php?script=sci_arttext\&pid=S1516-35982012000500033 >. doi: 10.1590/S1516-35982012000500033

NAZARENO, A. C.; SILVA, I. J. O.; VIEIRA, F. M. C.; SANTOS, R. F. S. Temperature mapping of trucks transporting fertile eggs and day-old chicks: Efficiency and/or acclimatization?. Revista

Brasileira de Engenharia Agrícola e Ambiental, Campina Grande, v.19, p.134-139, 2015a. Disponível em: <http://www.agriambi.com.br/revista/v19n02/v19n02a07.pdf>. doi: 10.1590/18071929/agriambi.v19n2p134-139

NAZARENO, A. C.; SILVA, I. J. O.; VIEIRA, F. M. C.; SANTOS, R. F. S. One day-old chicks transport: Assessment of thermal profile in a tropical region. Revista Brasileira de Engenharia Agrícola e Ambiental, Campina Grande, v.19, p.663-667, 2015b. Disponível em: <http://www.agriambi.com.br/revista/v19n02/v19n02a07.pdf > doi: 10.1590/18071929/agriambi.v19n7p663-667

ONMAZ, A.C.; VAN DEN HOVEN, R.; GUNES, V.; CINAR, M.; KUCUK, O. Oxidative stress in horses after a 12-hours transport period. Revue de Médecine Vétérinaire, Toulouse, v.162, p.213217, 2011. Disponível em: <http://www.revmedvet.com/2011/RMV162_213_217.pdf>.doi: 10.1186/1751-0147-55-58

QUINN, A. D.; BAKER, C. J. An investigation of the ventilation of a day-old chick transport vehicle. Journal of Wind Engineering and Industrial Aerodynamics, Amsterdam, v.67, p.305311, 1997. Disponível em: < http://ac.els-cdn.com/S0167610597000810/1-s2.0S0167610597000810-main.pdf?_tid=53fd502e-dc68-11e4-913b00000aab0f26\&acd nat=1428330317_569e34e36fe998397e0416aa853672e6> . doi:10.1016/S01676105(97)00081-0

RODRIGUES, V. C.; SILVA, I. J. O.; VIEIRA, F. M. C.; NASCIMENTO, S. T. A correct enthalpy relationship as thermal comfort index for livestock. International Journal of Biometeorology, Heidelberg, v. 55, p. 455-459, 2011. Disponível em:

<http://download. springer.com/static/pdf/828/art\%253A10.1007\%252Fs00484-010-0344y.pdf?auth66=1418815339_f00e8892de91ee4b613eaa762a3bc3a1\&ext=.pdf $>$. doi: 10.1007/s00484-010-0344-y

SAS Institute. Statistical analysis system: realease 9.2, (software). Cary, 2010. 620p.

SAMPAIO, I. B. M. Estatística aplicada à experimentação animal. 3. ed. Belo Horizonte: Fundação de Estudo e Pesquisa em Medicina Veterinária e Zootecnia, 2007. 264p.

SCHIMIDT, G. S.; FIGUEIREDO, E. A. P.; SAATKAMP, M. G.; BOOM, E. R. Effect of storange period and egg weight on embryo de velopment and incubation results. B razilian Journal of Poultry Science, Campinas, v.11, p.1-5, 2009. Disponível em: < http://www.scielo.br/scielo.php?pid=S1516-635X2009000100001\&script=sci_arttext $>$.doi: 10.1590/S1516-635X2009000100001 
TATEO, A.; PADALINO, B.; BOCCACCIO, M.; MAGGIOLINO, A.; CENTODUCATI, P. Transport stress in horses: effects of two different distances. Journal of Veterinary Behavior: Clinical Applications and Research, Amsterdam, v.7, 33-42, 2012. Disponível em: < http://ac.elscdn.com/S1558787811000712/1-s2.0-S1558787811000712-main.pdf?_tid=bf1 c10c2-dc66-11e494c5-00000aab0f02\&acdnat=1428329637_751b0f76722176c28d57cc3cda7c7010>. doi: 10.1016/j.jveb.2011.04.007

TZSCHENTKE, B. Attainment of thermoregulation as affected by environmental factors. Poultry Science, Sarvy, v.86, p.1025-1036, 2007. Disponível em:

<http://ps.oxfordjournals.org/content/86/5/1025.full.pdf+html>. doi: 10.1093/ps/86.5.1025

YAHAV, S.; SHINDER, D.; TANNY, J.; COHEN, S. Sensible heat loss: the broiler's paradox. World's Poultry Science Journal, Walling ford, v.61, p.419-434, 2005. Disponível em: < http ://journals.cambrid ge.org/action/displayAbstract?fromPage=online\&aid=619208\&fulltext Type $=$ RV \& fileId=S0043933905000309>. doi: 10.1079/WPS200453

YAHAV, S.; SHINDER, D.; RUZAL, M.; GILOH, M.; PIESTUM, Y. Controlling body temperature - the opportunities for highly productive domestic fowl. In: CISNEROS A.B.; GIONS, B.L. (Ed). Body temperature regulation. New York. Nova Science, 2009, p.65-98. 